\title{
GYMNOSPORANGIUM SPECIES - AN IMPORTANT ISSUE OF PLANT PROTECTION
}

\author{
Baiba Lāce \\ Institute of Horticulture, Latvia University of Agriculture, Graudu iela 1, Krimūnu pag., Dobeles nov., LV-3701, LATVIA; \\ baiba.lace@llu.lv
}

Communicated by Edite Kaufmane

\begin{abstract}
Rusts (Fungi, Basidiomycota, Pucciniomycotina, Pucciniomycetes, Pucciniales) are one of the most important causal agents of diseases and they are infecting many plants including cereals and field crops, vegetables, trees and many ornamentals. They have been studied for a long time and have economic importance among the plant diseases caused by agents of different species of fungi. In Europe, thirteen rust genera have been reported, of which the genus Gymnosporangium is the second largest after genus Phragmidium. The most significant fruit tree rust pathogen is the genus Gymnosporangium. The literature review shows quite limited scientific information about this genus and its species. Studies have mainly focused on some stages of the pathogen development cycle, which are significant for the spread of diseases - uredo and teleito stages. Special attention of the review was paid to European pear rust (caused by G. sabinae (Dicks.) G. Winter), the distribution of which has increased during the last ten years, especially in organic pear orchards. Currently there is a limited number of scientific publications about European pear rust, and they are mainly based only on observations in vitro without trials in the field, despite the fact that it has become one of the most devastating diseases. Therefore, the presented review analyses the rust exploration history, diversity and distribution of species, life cycle, development biology and plant protection issues.
\end{abstract}

Key words: plant disease, rusts, pear, species, life cycle.

\section{INTRODUCTION}

Rusts (Fungi, Basidiomycota, Pucciniomycotina, Pucciniomycetes, Pucciniales) are one of the most important causal agents of diseases and are infecting many plants including grain and field crops, vegetables, fruit trees and many ornamentals (Cummins and Hiratsuka, 2003). Rusts as plant diseases have been studied for a long time and they have economical importance among the plant diseases caused by agents of different species of fungi. The rust fungi belong to one of the largest groups of Basidiomycota - the order Pucciniales, family Pucciniaceae. Worldwide are described nearly 8000 species, 150 genera and 13 families of rust fungi (Aime, 2006; Toome and Aime, 2012). Rust causing pathogens are biotrophic fungi or obligate parasites of plants (for successful development of their life cycle they need only a living plant) (Deacon, 2006). In contrast to saprophytic pathogens, rusts pathogens feed and develop on plants without killing them.

The rust pathogens significant for fruit trees belong to genus Gymnosporangium (Helfer, 2005), which mostly affects the plants of Cupressaceae - cypress (Cupressus) and junipers (Juniperus) and Rosaceae - hawthorns (Crataegus), apples (Malus), pears (Pyrus), quinces (Cydonia), shadberries (Am- elanchier) and rowan (Sorbus) (Kern, 1911; Dodge, 1915). More than a half $(54 \%)$ of Rosaceae species plants are highly susceptibile to rust fungi (Helfer, 2005).

Gymnosporangium are unique rust fungi, which telia stage developes only on the gymnosperms (Aime, 2006). Pathogens of Gymnosporangium develop the aecia stage on the Rosaceae host (secondary or alternate host) and the telia stage on cedars and junipers (primary or telia host) (Kern, 1911; Helfer, 2005). The most common worldwide distributed diseases caused by Gymnosporangium species are cedar apple rust (caused by G. juniperi-virginianae Schwein.), Japanese pear rust (G. asiaticum Miyabe ex G. Yamada) (Cummins and Hiratsuka, 2003) and European pear rust (G. sabinae (Dicks.) G. Winter), the distribution of which has significantly increased during the last years, especially in organic pear orchards (Fillip et al., 2012; Kellerhals et al., 2012).

\section{RESEARCH HISTORY}

Different rust diseases have been mentioned already in documents of the ancient world. In the notes of Aristotle (384-322 BC) and Theophrastus (371-287 BC) the rust of 
cereals was mentioned, and the ancient Romans adored rust God Robigo (Kolmer et al., 2009; Sharma, 2014). They were recognised as plant diseases and pathogens only in 1767 , by Italian natural scientists Felice Fontana and Targioni-Tozzetti, who investigated and described the morphology of teliospores and urediniospores (Ainsworth, 1981). The name of rust fungi was introduced due to the orange color of spore masses, which can be observed on the infected plants (Kolmer et al., 2009).

The genus Gymnosporangium also has been studied for a very long time, e.g. already in the $18^{\text {th }}$ century scientists payed attention to fungal diseases on junipers. The first study about the genus Gymnosporangium focused on the telia stage on Juniperus communis and it was published by C. Linnaeus (Linnaeus, 1753). In 1785, J. J. Dickson published description of Tremella sabinae (the synonym of Gymnosporangium sabinae) (Belomesyatseva, 2004), while A. P. De Kandolle (1805) in the mycological literature described the Gymnosporangium genus, reporting three species - G. fuscum DC., G. conicum Hedw. and G. clavariaeforme Jacq. Only in 1865, during experiments by A. S. Oersted it was discovered that the telia stage on juniper and aecial stage on the pear are different development stages of the same pathogen life cycle. Oersted's experiment was an important starting point for more detailed studies on the genus Gymnosporangium, and all the most significant Gymnosporangium species were identified during the $20^{\text {th }}$ century. The first results on Gymnosporangium spore morphology appeared at the end of the $19^{\text {th }}$ century. Several studies focused on the determination of host plants for various species of the genus Gymnosporangium (Thaxter, $1886 ; 1889 ; 1891)$. Variation of morphology in different stages of spore development was observed during study of the gelatinous mass of Gymnosporangium clavariaeforme, assuming presence of the uredo stage (Richards, 1889). However, later in 1908, F. D. Kern (1908) described Gymnosporangium as heteroecious rusts with absent uredo stage in all known species of the genus. Significant contribution to the investigation of the genus Gymnosporangium was given by Professor F. D. Kern (1883-1973). Already in his doctoral thesis, he summarised results of studies on Gymnosporangium since 1906, and published one of his the most notable works "A biologic and taxonomic study of the genus Gymnosporangium" (1911). F. D. Kern devoted his whole life to studies of the genus Gymnosporangium and in 1973 published the monograph A revised taxonomic account of Gymnosporangium (Boyle et al., 1974). Although the rust diseases have been studied for a long time, there are still unclear questions on the Gymnosporangium genus and its species.

\section{DISTRIBUTION}

Rusts are distributed worldwide, while most rust species are found in temperate regions of the northern hemisphere, as well as in tropical and subtropical regions, where new genera and species of rusts are still identified (Hiratsuka and Sato, 1982; Horst, 2013). In Europe 13 rust genera are re- ported, of which the genus Gymnosporangium is the second largest after genus Phragmidium (represented by 15 species) and the most significant rust pathogens for fruit trees belong to this genus. At the beginning of the 21 st century, nine species of Gymnosporangium were described in Europe - G. fusisporum, G. torminali-juniperinum, G. amelanchieris, G. confusum, G. tremelloides, G. gracile, G. clavariiforme, G. sabinae and G. cornutum (Table 1, according to Helfer, 2005).

In Turkey seven species of this genus were found: G. amelanchieris, G. clavariiforme, G. confusum, G. cornutum, G. dobrozrakovae, G. sabinae, and G. tremelloides (Dinē and Yilmaz, 1978; Hüseyinov, 2000; Bahçecioğlu, 2001; Hüseyinov and Selçuk, 2001; Erdoğdu et al., 2010; Dervis et al., 2010). Studies on distribution of the genus Gymnosporangium have been mainly performed in different regions of North America, where more species have been identified (Cummins and Hiratsuka, 2003). At the beginning of the $20^{\text {th }}$ century, in total 27 species of Gymnosporangium (according to the telia host) and 45 species (according to the aecia host) were identified, including only 8 species (according to the telia host) and 14 species (according to the aecia host) in Europe (Kern, 1911). Currently about 60 species of Gymnosporangium are known and they are distributed worldwide (Kern, 1973; Cummins and Hiratsuka, 1984; Farr et al., 1995).

Table 1

SPECIES OF GENUS GYMNOSPORANGIUM IN EUROPE*

\begin{tabular}{|c|c|c|}
\hline Species & Primary hosts & Secondary hosts \\
\hline G. fusisporum & Juniperus sabina & Cotoneaster \\
\hline G. torminali-juniperinum & Juniperus & Sorbus \\
\hline G. amelanchieris & Juniperus oxycedrus & $\begin{array}{l}\text { Amelanchier, } \\
\text { Pyracantha }\end{array}$ \\
\hline G. confusum & $\begin{array}{l}\text { J. oxycedrus, } \\
\text { J. sabina }\end{array}$ & $\begin{array}{l}\text { Cotoneaster, } \\
\text { Crataegus, } \\
\text { Cydonia oblonga, } \\
\text { Mespilus germanica, } \\
\text { Pyracantha coccinea } \\
\text { Pyrus communis } \mathbf{L} ., \\
\text { Sorbus aucuparia, }\end{array}$ \\
\hline G. tremelloides & J. oxycedrus & $\begin{array}{l}\text { Cydonia oblonga, } \\
\text { Malus, } \\
\text { Sorbus }\end{array}$ \\
\hline G. gracile & Juniperus & $\begin{array}{l}\text { Amelanchier ovalis, } \\
\text { Crataegus monogyna, } \\
\text { Cydonia oblonga }\end{array}$ \\
\hline G. clavariiforme & J. communis & $\begin{array}{l}\text { Amelanchier, } \\
\text { Crataegus, } \\
\text { Cydonia oblonga, } \\
\text { Malus, } \\
\text { Pyrus, } \\
\text { Sorbus, }\end{array}$ \\
\hline G. sabinae & $\begin{array}{l}\text { J. communis, } \\
\text { J. sabina }\end{array}$ & Pyrus \\
\hline G. cornutum & J. oxycedrus & Sorbus \\
\hline
\end{tabular}

* According to Helfer, 2005 
Gathering information from the European herbariums, databases and local flora, Helfer (2005) reported that in the Baltic region (including Estonia, Latvia, Lithuania and the Kaliningrad region of Russia), there are four species $-G$. tremelloides, G. clavariiforme, G. sabinae, G. cornutum. Since the hosts of these Gymnosporangium species, junipers J. communis and J. sabina are commonly found also in Latvia (Enescu et al., 2016), only the spread of species $G$. sabinae and $G$. clavariiforme is likely possible in Latvia. Since $J$. oxycedrus is distributed only in the Mediterranean regions (Vilar et al., 2016), the species G. tremelloides and G. cornutum theoretically can not occur in Latvia, which contradicts Helfer's (2005) published information.

\section{LIFE CYCLE}

The life cycle of rust fungi is very complicated and plastic - at least 17 different development cycles are known around the world (Figueiredo, 2000). The most common are macrocyclic and heteroeciouis life cycles. The fungus develops five types of spore - spermagonia produces spermatia and receptive hyphae (stage 0 ), aecium produce aeciospores (stage 1), uredium - urediospores (stage 2), telium - teliospores (stage 3) and basidium - basidiospores (stage 4) and therefore two hosts are necessary for the complete life cycle. In the demicyclic life cycle the uredia stage is absent, but rust misses also the aecia stage in the microcyclic life cycle. Some rust species can complete their life cycle on one host - the autoecious rusts (Cummins and Hiratsuka, 2003; Kolmer et al., 2009).

Usually fungi of Gymnosporangium have four different types of spores in the development cycle (Juhasova and Praslieka, 2002; Aime, 2006; Börner, 2009). J. C. Arthur in 1916 described the uredial stage of $G$. nootkatense Arthur (Arthur, 1916). Later in 1949, the uredial stage was found on Juniperus nana (G. gaeumannii H. Zogg) in Switzerland by Zogg Hanss, and in 1960 on leaves of Calocedrus macrolepis Kurz in Vietnam (G. paraphysatum Vienn.Bourg). In contrast, Gymnosporangium sabinae is obligate parasite on plants and represents a heteroecious, demicyclic (with absent uredinia) rust, which overwinters in juniper twigs (Cummins and Hiratsuka, 2003; Börner, 2009). Gymnosporangium is the only genus of the rust fungi having a teleito stage that developes on gymnosperms (Aime, 2006).

\section{EUROPEAN PEAR RUST CAUSED BY GYMNOSPO- RANGIUM SABINAE}

Pears are the secondary host for species G. confusum, $G$. clavariiforme, and G. sabinae (Kern, 1973; Helfer, 2005); however, $G$. sabinae is economically the most important and disastrous among all Gymnosporangium species and the most devasting for pears (Helfer, 2005). European pear rust caused by G. sabinae is widespread in Europe. In the 1970s, in Sweden, due to the popularity of junipers European pear rust spread in the southern part of country, but during recent years it has spread also further north (Karlsson, 2008; Ivarsson, 2011). In the autumn of 2005, European pear rust symptoms were identified on pears in home gardens in Norway and in spring 2006 the telial stage was observed on junipers (Gjærum et al., 2008).

The development of European pear rust starts in early spring on junipers (normally Juniperus sabina, J. virginia, J. chinensis). There appear fusiform conical or laterally compressed gelatinous swellings $(2-3 \times 4-6 \mathrm{~mm}$ in size $)$ in dark brown, later orange colour, in which develop two celled, ellipsoid to oblong nearly colourless to dark brown, teliospores $(28-72 \times 16-39 \mu \mathrm{m}$ in size $)$ with $1-3 \mu \mathrm{m}$ in size thick walls. During futher development, basidiospores are produced, which later infect pear leaves, shoots and fruits (Cummins and Hiratsuka, 2003). The first symptoms on pear may occur one month after infection. It appears at the top of the leaves as yellow-orange spots, which gradually become larger $(5-10 \mathrm{~mm})$. Later spermogonia develop in the middle of the spots, the structure of which conforms to group V (type 4) (Hiratsuka and Hiratsuka, 1980). At the end of summer until leaf fall, dark brown aeciospores (21-27 $\times 24-30 \mu \mathrm{m}$ in size) with wall thickness 3-4.5 $\mu \mathrm{m}$ develop in globoid to ellipsoid roestelioid, hypophyllous aecia (0.5-1 mm diameter, 2-5 mm length), (Cummins and Hiratsuka, 2003). The peridium tear, releasing aeciospores by wind to the junipers, where they hibernate (Hilber and Siegfried, 1989).

In various parts of the world, teliospore formation starts at different times - in Slovakia at the end of April, beginning of May (Juhasova and Praslieka, 2002), in Switzerland in early April (Hilber et al., 1990), and in Germany (Berlin Brandenburg region) the end of March (Gebauer et al., 2001). High relative humidity and water droplets on leaves promote formation of teliospores and basidiospores (Hilber and Siegfried, 1989). Studies on Gymnosporangium sabinae infection biology (Hilber et al., 1990) revealed the optimal conditions for spore germination and distribution in vitro, but systematic studies in field conditions have not been performed.

A large number of basidiospores are distributed from infected junipers, but not all of them can infect pears; however even relatively poor spore material can cause rust epidemics. Formation and distribution of basidiospores have impact on the severity of rust, which is influenced also by ability of spores to penetrate plant tissue, wind speed and direction (Hau and De Vallavieille-Pope, 2006). Each of these factors can be modified by certain weather conditions (Mitrofanova, 1970; Pearson et al., 1980). Although viability of basidiospores is low and they can not overpass long distances by wind (Agrios, 1997), mycologists R. Thaxter (1891) and H. Hughes (1958) reported that basidiospores can cause low infection of pears even $60 \mathrm{~km}$ away from the source of infection (Mitrofanova, 1970). Basidiospores of G. juniper-virginianae (causes apple - cedar rust) are able to overcome distances of 3-5 km (Agrios, 1997). Strong infection occurs when the pear trees and junipers grow near, not further than 300 to 500 m (Mitrofanova, 1970; De Ryck, 
2001). A study on the severity of European pear rust in relation to the location of junipers found that when pears were located at $30 \mathrm{~m}$ distance from the juniper, $100 \%$ pear leaves were infected, $150 \mathrm{~m}$ away $-50 \%$ of the leaves, and $300 \mathrm{~m}$ - no symptoms of disease was observed on leaves (Ormrod, et al., 1984).

Temperature and relative humidity has impact on the sporulation intensity of the pathogen (Hau and De Vallavieille-Pope, 2006). The range for germination of basidiospores is wide, and can take place at temperatures from 5 to $20{ }^{\circ} \mathrm{C}$, with optimal temperature of germination $15{ }^{\circ} \mathrm{C}$ (Hilber et al., 1990; Dong et al., 2006). The optimal relative humidity $(\mathrm{RH})$ is $84-91 \%$, whereas at $\mathrm{RH} 97 \%$ the ability of spores to infect leaves decreases (Mitrofanova, 1970). Basidiospores are very sensitive to drying out, insufficient moisture and direct sunlight can affect their viability (Gold and Mendgen, 1991). The period of basidiospore release depends on weather conditions, but generally it coincides with the phenological stage of pome fruit — "wollen bud" (Meier, 2001). Basidiospore release occurs 4-6 hours after rain (average air temperature $8{ }^{\circ} \mathrm{C}$ ) and it can last for 14 hours (Mitrofanova, 1970). An early and wet spring is not necessary for sporulation and every year the number of sporulations differs, for example, in Crimea sporulation occurred between 4-9 times (Mitrofanova, 1970), in Switzerland - three times (Hilber et al., 1990a). The most critical period is when the average temperature rises rapidly and heavy rains occur in pear orchards. The primary, main infection takes place usually once in spring, when the average temperature is $13-15^{\circ} \mathrm{C}$. The next sporulations do not have significant impact on pear orchards (Mitrofanova, 1970; Hilber et al., 1990a). A late and dry spring is not favorable for development and release of basidiospores. The period of infection can be from mid-April until the end of May (Mitrofanova, 1970). The infection is dependent on the age of pears leaves, especially susceptible are 10 days old leaves (Mitrofanova, 1970). A study on related a species (G. juniper-virginianae) showed that 4-, 6- and 8-day-old apple leaves were more susceptibile than the 10- and 12day-old leaves (Aldwinckle et al., 1980).

Basidiospores can infect only the secondary host - pear (Schildberger, 2011). Spores enter through the parenchyma of plant green parts and after some time the first symptoms of disease appear — spots (Hilber et al., 1990a; Schildberger, 2011). Symptoms occur on the leaves, fruits and branches. Small dark dots develop in the middle of these spots - spermagonia, where single mating type spermatia are developing (Agrios, 1997; Schildberger, 2011). Spermatia produce a sweet liquid, which is food for insects and helps to distribute spermatia to others with a different mating type. Both spermatia of one mating type and spermatia of the opposite mating types interflow with receptive hyphae. By this time, dikaryotic mycelium has been developed and it produces an aecium containing aeciospores (Mitrofanova, 1970; Agrios, 1997). Aecium develop on the bottom of leaves and it grows for 140 days after infection. When aeciospores are mature (usually during 20 days), horns of aecium burst and spores release (Mitrofanova, 1970). Aeciospores of $G$. sabinae can be spread by wind over long distances up to defoliation. Aeciospores can infect only junipers. They return to the junipers, infect and hipernate in branches, completing the life cycle (Börner, 2009; Hilber and Siegfried, 1989; Schildberger, 2011).

\section{EUROPEAN PEAR RUST IN LATVIA}

In Latvia European pear rust for the first time was mentioned in 1938 by M. Eglītis (Eglītis, 1938), where it was characterised as widespread and a damaging disease only in Western Europe, but which is not found in Latvia. Later this disease was not mentioned for pears at all. Some sporadic information about European pear rust appeared only in popular publications and online resources, which associated the distribution of the disease in Latvia with popularity of junipers in late 1990s (Eihe, 2004). Scientific studies on severity of European pear rust in Latvia were started in 2007, when symptoms of the disease were found in more than half of 33 surveyed pear orchards. The disease was found throughout the whole territory of the country and the highest severity was observed in the middle part — Zemgale (Rancane et al., 2012). In 2013, distribution of disease increased also in the western part - Kurzeme.

Pear orchards of different regions of Latvia were screened for incidence of European pear rust, and disease development was investigated for three years at the pear collection of the Institute of Horticulture, Latvia University of Agriculture (former Latvia State Institute of Fruit-Growing). Severity of pear rust was scored using scale of points (0-5) indicating average number of infected leaves per tree. European pear rust severity results showed significant difference over the years of evaluation. The incidence and spread of the disease was higher during more humid growth periods (Rancane et al., 2012). Like in other studies (Kellerhals et al., 2012) completely resistant cultivars were not found among the tested ones, but susceptibility was variable (Lāce and Bankina, 2013). This study also discovered dependence of disease severity on the tree location in the orchard. More infected trees were located at the edges of the trial block, but in the middle of orchard the infection was lower, regardless of the cultivar (Lāce and Lācis, 2015). High severity of European pear rust infection showed significant influence on pear yield (Prokopova, 2011; Rancane et al., 2012).

\section{EUROPEAN PEAR RUST CONTROL OPTIONS}

Successful fruit crop growing should be based on a complex system, which includes agro-technical, biological and chemical plant growing and protection measures, resistant plant material. Traditionally, worldwide European pear rust is controlled by fungicide applications, like other diseases caused by fungi (Ormrod et al., 1984; Agrios, 1997; Fischer and Weber, 2005). For example, in apple-growing regions the control of scab (caused by Venturia inaequalis), glob- 
ally the economically most important disease, 12 to 30 sprays need to be applied during the growing season (Soufflet-Freslon et al., 2008; Soriano et al., 2009), and the control overlaps with other fungal diseases, including rust control (Holb, 2013). Although the distribution of European pear rust can be limited by application of pesticides (Ormrod et al., 1984), pesticide use in home gardens and organic orchards is not supported.

The task of agro-technical methods is ensuring favorable conditions for fruit crop growing, but which are unfavorable for pest development and spread. It is known that a balanced use of fertilisers, proper tillage, and seasonable thinning of the tree crown increases resistance to various pathogens and reduces to a minimum the applications of chemical plant protection products (Mitrofanova, 1970; Agrios, 1997). Pear orchards should be planted as far as possible away from the sources of infection (at least $3 \mathrm{~km}$ ) and they should be enclosed by windbreaks. Crown thinning and illuminating have and essential role, which ensures quick drying of leaves after rain and causing unfavorable conditions for the growth of pathogen (Mitrofanova, 1970). During the winter period of tree dormancy, pear and juniper branches infected with rust can be cut and wounds treated with disinfectants (Mitrofanova, 1970; Hunt and O'Reilly, 1978). Similarly, the disease severity can be controlled by removal of gelatinous teleito horn colonies from infected juniper branches before release of basidia spores (Hilbers and Siegfried, 1989). Some authors recommend the destruction of one of the host species in the case of disease appearence (Fischer and Weber, 2005). The possible, application of net covers during the infection period also has been shown to limit European pear rust, but positive effect was observed only for new trees or trees on dwarfing rootstocks, and covers should be removed timely to prevent twists in young shoot growth and spoilage of leaves (Ivarsson, 2011). Plant supply with sufficient quantities of nutrients essential for development is one of the most important requirements for high and stable yields; however, fertiliser doses must be balanced. High concentration of nitrogen in leaves promotes favorable conditions for the development of many pathogens, including European pear rust agent (Agrios, 1997; Hau and De Vallavieille-Pope, 2006).

Use of resistant plant material is one of the sustainable fruit growing options. Different defence mechanisms exist both in plants and pathogens, which could be used successfully in plant protection systems against biotrophic pathogens (Dangl et al., 1996; Govrin and Levine, 2000; Iakimova et al., 2005; Jones and Dangl, 2006; Boyd et al., 2013). Hypersensitive response (HR) is one of the most characteristic plant defense mechanisms, when plant cells die around the infection point thus preventing its further spread. It is a protective response against pathogenic infection and appears in case of interaction between a resistant plant genotype and avirulent pathogen (Heath, 2000; Shirasu and SchulzeLefert, 2000). HR mechanism is blocking development of pathogen haustoria before its entrance into the plant cell, by activating the mechanisms of plant tissue death, thereby de- stroying the pathogen (Bennett et al., 1996; Naton et al., 1996). Research on HR in fruit crops is limited - mainly studies are focused on molecular mechanisms of resistance and biotechnology of resistant cultivars, but the physiological and biochemical mechanisms of HR are still insufficiently studied (Iakimova et al., 2005). Identification and growing of pear cultivars characterised by HR reaction to European pear rust infection can limit the spread of disease, since completely immune $P$. communis cultivars do not occur naturally. Typically, they are more or less susceptible cultivars, and evaluation results can be contradictionary, e.g. in Crimea cultivars 'Fondante des Bois' and 'Beurre Bosc' were highly susceptible, but the cultivar 'Clapp's Favourite' - less susceptible (Mitrofanova, 1970). In the Netherlands during 60 pear cultivar screening for resistance to certain fungal diseases, some symptoms of European pear rust were observed only on cultivar 'Erika' (Kemp and van Dieren, 2000), whereas no resistant cultivars were identified during the five-year study in a Belgian cultivar collection (Kellerhals et al., 2012). Resistance of different Pyrus species to European pear rust was studied by Fitzner and Fischer (2005) and species Pyrus korzhinskyi, P. betulifolia, $P$. cordata and hybrid $P$. salicifolia 'Pendula' were selected as resistant and recommended for use in landscaping as well as donors in breeding.

Sustainable fruit growing accepts and promotes application of biological control means. Several studies showing positive and successful results in rust biological control using pathogenic fungi were identified. Dolinska and Schollenberger (2011) in Poland found twisting and death of Gymnosporangium spp. aecial spores caused by conidia and conidia spores of the pathogen Cladosporium uredinicola. According to published information, there are over 150 species of parasitic fungi (from 15 genera) that hamper the development cycle of rust fungus. The most common fungus, natural parasite of rust aecidial stage Tuberculina persicina Ditm. Sacc. was mentioned for the first time at the beginning of the 19th century under the name Tubercularia persicina (Ditmar, 1817), the fungus acquired its current name at the end of the same century (Saccardo, 1880). Fungi of the genus Tuberculina are mitosporic parasites of rust fungi. Only three of thirty seven Tuberculina species are widely described and studied - T. maxima, $T$. persicina, $T$. sbrozzii (Wicker, 1981; Lutz et al., 2004b; Shamsi and Naher, 2010). Tuberculina is an anamorph stage of Helicobasidium genus rust parasites (according to Lutz et al., 2004a). Dominic Begerov studied genes of Tuberculina and rust fungi and found close relatedness, despite species differences (Lutz et al., 2004b). In Crimea during the appearance of rust spots on leaves, pears were sprayed with spore suspensions of $T$. persicina, which stopped the growth of spots (Mitrofanova, 1970). During contact of the suspension with infected leaves, $T$. persicina hyphae grew into the aecial spores, hampering their development (Bartkowska, 2007), whereas spots on nontreated leaves continued to grow, increasing 35 times. Sprays of the same spore suspension during occurence of aecia sets did not show differences bewteen sprayed and unsprayed leaves (Mitrofanova, 1970). 
T. persicina spore suspension can be applied effectively only when the first symptoms of rust appear on leaves. This control method can be used, when fungicide sprays will not protect the plant under several conditions, like rain, heavy wind (Mitrofanova, 1970). In Latvia, Tuberculina maxima was found in Ādaži parish and identified in 1951 (Smarods, 1951), and T. persicina - in 1947, but there are no reports on their use in rust control (Smarods, 1947).

\section{CONCLUSIONS}

Some Gymnosporangium species, especially important fruit crop pathogens, are known for a long time, however many aspects of their distribution and life cycle are still not well understood. Special attention should be paid to the plantpathogen interaction mechanisms, and their use in the sustainable plant protection systems. More detailed information on climate condition impact on pathogen development, and its pathogenicity, would be necessary in context of possible climate changes and forecasting of potential disease outbreaks. Implementation of biological control means for pathogens of genus Gymnosporangium is an important challenge for sustainable fruit growing, which requires detailed knowledge on possible control agents, and their interaction with pathogens.

Currently, an Integated Pest Managment system for this pear disease has not been established, but fungicide sprays on the basis of the pathogen life cycle is the beginning of the development of an integrated disease control system.

\section{REFERENCES}

Agrios, G. N. (1997). Plant Pathology. Fourth edition. Academic Press, San Diego. 637 pp.

Aime, M. C. (2006). Toward resolving family-level relationships in rust fungi (Uredinales). Mycoscience, 47 (3), 112-122.

Ainsworth, G. C. (1981). Introduction to the History of Plant Pathology. Cambridge University Press, Cambridge, West Nyack, New York, U.S.A. 332 pp.

Aldwinckle, H. S., Pearson, R. C., Seem, R. C. (1980). Infection periods of Gymnosporangium juniperi-virginianae on apple. Phytopathology, 70, 1070-1073.

Arthur, J. C. (1916). A gymnosporangium with repeating spores. Amer. J. Bot., 3, 40-45.

Bahçecioğlu, Z. (2001). New records of Pucciniaceae from Turkey. Plant Dis. Res., 16, 17-22.

Bartkowska, A. (2007). Ultrastructural examinations of the parasitic contact of Tuberculina persicina with Puccinia caricina and Puccinia graminis. Phytopathol. Polon., 43, 69-76.

Belomesyatseva, D. B. (2004). World survey of juniper-associated fungi. Mycena, 4, 127.

Bennett, M., Gallagher, M., Fagg, J., Bestwick, C., Paul, T., Beale, M., Mansfield, J., (1996). The hypersensitive reaction, membrane damage and accumulation of autofluorescent phenolics in lettuce cells challenged by Bremia lactucae. Plant J., 9, 851-865.

Börner, H. (2009). Pflanzenkrankheiten und Pflanzenschutz. SpringerVerlag, Berlin (Heidelberg). $708 \mathrm{~S}$.
Boyd, L. A., Ridout C., O’Sullivan, D. M., Leach, J. E., Leung, H. (2013). Plant-pathogen interactions: Disease resistance in modern agriculture. Trends Gen., 29, 233-240.

Boyle, J. S., Fergus, C. L., Schein, R. D. (1974). Frank D. Kern. Phytopathology, 6, 766.

Cummins, G. B., Hiratsuka, Y. (1984). Families of Uredinales. Rep. Tottori Mycol. Inst., 22, 191-208.

Cummins, G. B., Hiratsuka, Y. (2003). Illustrated Genera of Rust Fungi. American Phytopathological Society, St. Paul, MN. 240 pp.

Dangl, J. L., Dietrich, R. A., Richberg, M. H. (1996). Death don't have no mercy: Cell death programs in plant-microbe interactions. Plant Cell, 8 , 1793-1807.

De, Ryck, A. (2001). Will pear rust (Gymnosporangium fuscum $=G$. sabinae) become important? Fruitteelt Nieuws, 14, (11), 6-7.

Deacon, J. (2006). Fungal Biology. Wiley-Blackwel, Hoboken, NJ. 371 pp.

Dervis, S., Dixon, L., Došanlar, M., Rossman, A. (2010). Gall production on hawthorns caused by Gymnosporangium spp. in Hatay province, Turkey. Phytoparasitica, 38, 391-400.

Dinē, N., Yilmaz, M. A. (1978). Investigation on Gymnosporangium spp. in eastern and southern areas of Turkey. J. Turkish Phytopathol., 7, 99-104.

Ditmar, F. (1817). Die Pilze Deutschlands: Tuberculina persicina. In: Sturm, J. (Ed.). Deutschlands Flora in Abbildungen nach Natur mit Beschreibungen. Lange, Nurnberg, S. 98-100. Available at:

http://www.indexfungorum.org/names/NamesRecord.asp?RecordID=153 382 (accessed 10 March 2016).

Dodge, B. O. (1915). The effect of the host on the morphology of certain species of Gymnosporangium. Bull. Torrey Bot. Club, 42, 519-544.

Dolińska, T., Schollenberger, M. (2011). Relationship between Gymnosporangium sabinae (pear rust) and Cladosporium herbarum. Progr. Plant Protect., 51 (2), 644-647.

Dong, X.-L., Li, B.-H., Zhang, Z.-F., Li, B.-D., Xu, X.-M. (2006). Effect of environmental conditions on germination and survival of teliospores and basidiospores of the pear rust fungus (Gymnosporangium asiaticum). Eur. J. Plant Pathol., 115, 341-350.

Eglitis, M. (1938). Plant Diseases [Augu slimības.] Zemnieka Domas, Rīga. 455 pp. (in Latvian).

Eihe, M. (2004). New disease in pear orchards [Bumbieru stādījumus apdraud jauna slimība]. Agrotops, 1, 38-39 (in Latvian).

Enescu, C. M., Houston Durrant T., Caudullo G., de Rigo, D. (2016). Juniperus communis in Europe: Distribution, habitat, usage and threats. In: San-Miguel-Ayanz, J., de Rigo, D., Caudullo, G., Houston Durrant, T., Mauri, A. (eds.), European Atlas of Forest Tree Species. Publication Office of the European Union, European Commission, Luxembourg, p. 104.

Erdošdu, M., Hüseyin, E., Suludere, Z. (2010). Description of the rusts from Kemaliye (Erzincan, Turkey). Phytoparasitica, 38, 81-93.

Farr, D. F., Bills, G. F., Chamuris, G. P., Rossman, A. Y. (1995). Fungi on Plants and Plant Products in the United States. The American Phytopathological Society, APS Press, St. Paul, Minnesota, USA. 1225 pp.

Figueiredo, M. B. (2000). The plasticity of rust life cycles. O Biologico, 62 (1), 107-111.

Filipp, M., Spornberger, A., Schildberger, B. (2012). Monitoring of pear rust (Gymnosporangium sabinae) in Austria and implications for possible control strategies. In: The 15th International Conference on Organic FruitGrowing, February 20-22, 2012. Foerdergemeinschaft Oekologischer Obstbau e.V., Hohenheim, pp. 65-73.

Fischer, M., Weber, H. J. (2005). Birnenanbau Integriert und Biologisch. Eugen Ulmer, Stuttgart, Hohenheim. $164 \mathrm{~S}$.

Fitzner, S., Fischer, M. (2005). Bewertung von Pyrus — arten auf Befall mit Birnengitterrost (Gymnosorangium sabinae Dicks.). Erwebs - Obstbau, 47, 37-39. 
Gebauer, J., Ebert, G., Buttner, C. (2001). Birnengitterrost - eine zunehmende Gefahf in unseren Kleingarten. Gesunde Pflanzen, 53, 44-47.

Gjærum, H. B., Gauslaa, Y., Talgø, V. (2008). Gymnosporangium sabinae found in Norway. Plant Pathol., 57, 376.

Gold, R. E., Mendgen, K. (1991). Rust basidiospore germlings and disease initiation. In: Cole, G. T., Hoch, C. (eds.). The Fungal Spore and Disease Initiation in Plants and Animals. Plenum, New York, pp. 67-99.

Govrin, E. M., Levine, A. (2000). The hypersensitive response facilitates plant infection by the necrotrophic pathogen Botrytis cinerea. Curr. Biol., 10, 751-757.

Hau, B., De Vallavieille-Pope, C. (2006). Wind-dispersed diseases. In: Cooke, B. M., Jones, G. D., Kaye, B. The Epidemiology of Plant Diseases. Springer, Netherlands, pp. 387-416.

Heath, M. C. (2000). Hypersensitive response-related death. In: Lam, E., Fukuda, H., Greenberg, J. (eds.), Programmed Cell Death in Higher Plants. Springer Science+Business media, LLC, pp. 77-90.

Helfer, S. (2005). Overview of the rust fungi (Uredinales) occurring on Rosaceae in Europe. Nova Hedwigia, 81, 325-370.

Hilber, U., Schüepp, H., Schwinn, F. J. (1990). Studies on infection biology of Gymnosporangium fuscum DC. J. Plant Dis. Protect., 97 (3), 299-305.

Hilber, U., Schüepp, H., Schwinn, F. J., (1990a). Untersuchungen zur Entwicklung des Birnengitterrostes. Schweizer Zeitschrift für Obst und Weinbau, 126, 486-494.

Hilber, W., Siegfried, W. (1989). Gitterrost auf Birnbaum und WacholderSanierungsmassnahmnen bei starkem Befall. Schweizer Garten, 8, 23-28.

Hiratsuka, Y., Hiratsuka, N. (1980). Morphology of spermogonia and taxonomy of rust fungi. Rep. Tottori Mycol. Inst., 18, 257-68.

Hiratsuka, Y., Sato, S. (1982). Morphology and taxonomy of rust fungi. In: Scot, K. J., Chakravory, A. K. (eds.). The Rust Fungi. Academic Press, London, New York, pp. 1-36.

Holb, I. J. (2013). Apple scab management in organic fruit orchards: Epidemiology, forecasting and disease control strategies. Acta Horticult., 1001, $223-234$.

Horst, R. K. (2013). Rusts. In: Horst, R. K. Westcott's Plant Disease Handbook. Springer, Netherlands, pp. 341-362.

Hunt, R. S., O'Reilly, H. J. (1978). Overwintering of pear trellis rust in pear. Plant Dis. Rep., 62, (8), $659-660$.

Hüseyinov, E. (2000). New records of microfungi for Turkey. Israel J. Plant Sci., 48, 75-78.

Hüseyinov, E., Selēuk, F. (2001). Contribution to study of mycoflora of Turkey. II. Ascomycetous and basidiomycetous microfungi of forest trees and shrubs in the Black Sea coast (Rize Province). Mikologiya i Fitopatologiya, 35, 13-15.

Iakimova, E. T., Michalczuk, L., Woltering, E. J. (2005). Hypersensitive cell death in plants - its mechnisms and role in plant defence against pathogens. J. Fruit Ornamental Plant Res., 13, 135-158.

Ivarsson, K. (2011). Studies of environmental factors (temperature and relative humidity) effecting the development of pear rust (Gymnosporangium fuscum) and studies of control methods: Horticulture and Agricultural Science Department of Plant Protection Biology, Faculty of Landscape Planning, Sveriges lantbruksuniversitet, Alnarp. 30 pp.

Jones, J. D. G., Dangl, J. L. (2006). The plant immune system. Nature, 444, 323-329.

Juhasova, G., Praslieka, J. (2002). Occurrence and harmful effects of Gymnosporangium sabinae (Dicks.) in Slovak Republic. Plant Protection Sci., 38, 89-93.

Karlsson, K. (2008). The distribution of Gymnosporangium fuscum and its implication on pear cultivation in Sweden. Bachelor Project, Sveriges Lantbruksuniversitet, Alnarp, Sweden. Available at: http://ex-epsilon.slu.se/2199/1/pear_rust_bachelor.pdf.
Kellerhals, M., Szalatnay, D., Hunziker, K., Duffy, B., Nybom, H., Ahmadi-Afzadi, M., Höfer, M., Richter, K., Lateur, M. (2012). European pome fruit genetic resources evaluated for disease resistance. Trees, 26, 179-189.

Kemp, H., van Dieren, M. C. A. (2000). Screening of pear cultivars for resistance to fungal diseases (Venturia pirina, Nectria galligena). Acta Horticulturae, 538, 95-101.

Kern, F. D. (1908). Studies in the genus Gymnosporangium. Bull. Torrey Bot. Club, 35, 499-511.

Kern, F. D. (1911). A biologic and taxonomic study of the genus Gymnosporangium. Bull. New York Bot. Garden, 7, 391-483.

Kern, F. D. (1973). A host survey of Gymnosporangium. Mycopathol. Mycol. Appl., 51 (1), 99-101.

Kolmer, J. A., Ordonez, M. E., Groth, J. V. (2009). The rust fungi. In: Encyclopedia of Life Sciences (ELS). John Wiley \& Sons, Ltd Chichester, pp. $1-8$.

Lāce, B., Bankina, B. (2013). Evaluation of European pear rust severity depending on agro-ecological factors. In: Research for Rural Development 2013: Annual 19 ${ }^{\text {th }}$ International Scientific Conference Proceedings, 15-17 May 2013. Latvia University of Agriculture, Jelgava, pp. 6-12

Lāce, B., Lācis, G. (2015). Evaluation of pear (Pyrus communis L.) cultivars in Latvia. Horticult. Sci., 42, 107-113.

Linnaeus, C. (1753). Species plantarum, exhibentes plantas rite cognitas, ad genera relatas, cum differentiis specificis, nominibus trivialibus, synonymis selectis, locis natalibus, secundum systema sexuale digestas. Berolini: impensis G.C. Nauk, 2, 561-1200.

Lutz, M., Bauer, R., Begerow, D., Oberwinkler, F. (2004a). TuberculinaHelicobasidium: Host specificity of the Tuberculina-stage reveals unexpected diversity within the group. Mycologia, 96, 1316-1329.

Lutz, M., Bauer, R., Begerow, D., Oberwinkler, F. (2004b). Tuberculina Thanatophytum/rhizoctonia crocorum - Helicobasidium: A unique mycoparasitic — phytoparasitic life strategy. Mycol. Res., 108, 227-238.

Meier, U. (2001). Growth stages of mono and dicotyledonous plants. BBCH Monograph. Federal Biological Research Centre for Agriculture and Forestry, Bonn. 622 pp.

Mitrofanova, O. V. (1970). Pear Rust and Control Posibilities [Митрофанова, О. В. Ржавчина груши и меры борьбы с ней]. Izdatelstvo Krim, Simferopol. 46 pp. (in Russian).

Naton, B., Hahlbrock, K., Schmelzer, E. (1996). Correlation of rapid cell death with metabolic changes in fungus-infected, cultured parsley cells. Plant Physiol., 112, 433-444.

Ormrod, D. J., O'Reilly, H. J., van der Kamp, B. J., Borno, C. (1984). Epidemiology, cultivar susceptibility, and chemical control of Gymnosporangium fuscum in British Columbia. Canadian J. Plant Pathol., 6, 63-7.

Pearson, R. C., Seem, R. C., Meyer, F. W. (1980). Environmental factors influencing the discharge of basidiospores of Gymnosporangium juniperivirginianae. Phytopathology, 70, 262-266.

Prokopova, B. (2011). The severity of European pear rust depending on pear cultivars. Sodininkyste ir Darzininkyste, 30 (2), 43-50.

Rancane, R., Lace, B., Lacis, G. (2012). Distribution and development of European pear rust in Latvia and relationship between severity and yield. Integrated Plant Protection in Fruit Crops" Subgroup "Pome Fruit Diseases", IOBC-WPRS Bulletin (International Organization for Biological Control, West Palearctic Regional Section), 84, 39-45.

Richards, H. M (1889). The uredo-stage of Gymnosporangium. Bot. Gazette, 14 (9), 211-216.

Saccardo, P. A. (1881). Fungi Italici Autographice Delineati. Fascs 17-28, Patavii, Italy. Tabs 641-1120.

Schildberger, B. (2011). Untersuchungen zur Biologie des Birnengitterrostes (Gymnosporangium sabinae) und zum Befallsverlauf an der Birne. Wissenbericht, 173-176. 
Shamsi, S., Naher, N. (2010). Hypoparasitic fungus Tuberculina persicina (Ditm. Ex Fr.) sacc., as biocontrol agent for rusts. Dhaka Univ. J. Biol. Sci., 19, (1), 99-102.

Sharma, P. D. (2014). Principles of Plant Pathology. Rastogi Publications, New Delhi (India). 478 pp.

Shirasu, K., Schulze-Lefert, P. (2000). Regulation of cell death in disease resistance. Plant Mol. Biol., 44, 371-385.

Smarods, J. (1947). Retrieved from National Museum collection of Latvia (Latvijas Nacionālā Muzeja krājumi) database. Available at: http://www.nmkk.lv/Items/ItemViewForm.aspx?id=177841 (accessed 7 June 2017).

Smarods, J. (1951). Retrieved from National Museum collection of Latvia (Latvijas Nacionālā Muzeja krājumi) database. Available at: http://www.nmkk.lv/Items/ItemViewForm.aspx?id=177890 (accessed 7 June 2017).

Soriano, J. M., Joshi, S. G., van Kaauwen, M. Noordijk, Y., Groenwold, R., Henken, B., van de Weg W. E., Schouten, H. J. (2009). Identification and mapping of the novel apple scab resistance gene Vd3. Tree Genetics and Genomes, 5, 475-482.

Received 28 October 2016

Accepted in the final form 9 June 2017
Soufflet-Freslon, V., Gianfranceschi, L., Patocchi, A. Durel, C. E. (2008). Inheritance studies of apple scab resistance and identification of Rvi14, a new major gene that acts together with other broad-spectrum QTL. Genome, 51, 657-667.

Thaxter, R. (1886). On certain cultures of Gymnosporangium, with notes on their Rœsteliæ. Proc. Amer. Acad. Arts Sci., 22, 259-269.

Thaxter, R. (1889). Notes on cultures of Gymnosporangium made in 1887 and 1888. Botanical Gazette, 14 (7), 163-172.

Thaxter, R. (1891). The Connecticut species of Gymnosporangium (cedar apples). Bull. Connecticut Agricult. Exper. Station, 107, 1-6.

Toome, M., Aime, M. C. (2012, January). Pucciniomycetes. Available at: http://tolweb.org/\%20Pucciniomycetes/51246/2012.01.30 (accessed 11 August 2016).

Vilar, L., Caudullo, G., de Rigo, D. (2016). Juniperus oxycedrus in Europe: distribution, habitat, usage and threats. In: San-Miguel-Ayanz, J., de Rigo, D., Caudullo, G., Houston Durrant, T., Mauri, A. (eds.). European Atlas of Forest Tree Species. Publication Office of the European Union, European Commission, Luxembourg, p. 105.

Wicker, E. F. (1981). Natural control of white pine blister Rust by Tuberculina maxima. Phytopatalogy, 71, 997-1000.

\section{GYMNOSPORANGIUM SPP. — NOZĪMĪGA PROBLĒMA AUGU AIZSARDZĪBĀ}

Rūsas (Fungi, Basidiomycota, Pucciniomycotina, Pucciniomycetes, Pucciniales) ir patogēnās sēnes, kuras ir vienas no ekonomiski nozīmīgākās augu slimības ierosinātājiem. Tās var inficêt gan laukaugus, gan dārzaugus, gan dekoratīvos augus un kā augu slimību izraisītājas tās pētìtas jau ḷoti sen. Eiropā uz rožu dzimtas augiem aprakstītas 13 rūsas sẹnu ğintis, no kurām augḷu kokiem nozīmīgie patogēni pieder pie Gymnosporangium ǵints, kas ir otra lielākā aiz Phragmidium ǵints. Par aug̣̣augiem nozīmīgām rūsu slimībām, tai skaitā bumbieru-kadiḳu rūsu (ierosinātājs Gymnosporangium sabinae (Dicks.) G. Winter), zinātniskajā literatūrā pieejams ierobežots skaits publikāciju. Galvenokārt pētījumi par rūsu slimībām un to ierosinātājiem koncentrējas uz attīstības cikla atsevišḳām stadijām, visbiežāk uz tām, kas nozīmīgas slimības izplatībā — uredo un teleito stadijām. To attīstība pētīta tikai optimālos apstākḷos in vitro bez ilggadīgiem lauka pētījumiem. Literatūras apskatā apkopota pieejamā informācija par Gymnosporangium geinti, tās izpētes vēsturi, daudzveidību, sugu izplatību, t.sk. Latvijā, dzīves ciklu, patogēnu biolog̣iju un ierobežošanas iespējām. 